Law and Critique Vol.VII no.2 [1996]

\title{
THE INVISIBLE AUTHOR OF LEGAL AUTHORITY*
}

by

\author{
WiLLIAM E. CONKLIN ${ }^{* *}$
}

A strain of thought in Critical and Feminist legal scholarship suggests that if only juridical officials could break from the engendered and class conceptions or forms of legal discourse, judge and client would communicate interaubjectively in concrete, face-to-face social relations. Transformed social relations would be direct, immediate and concrete. The victim of reified legal doctrines would be recognised on her/his own terms. The barrier to the legal recognition of women's experiences, for example, has been understood as conceptual to the exclusion of the role of the sign which represents a category. ${ }^{1}$ Before the dominant conceptions are imposed, there exist concrete experiences best associated with the female gender. Indeed, generality and universalism characterise legal conceptions, thereby divesting people of "real individual life. ${ }^{.2}$ Mirroring

- An earlier draft of part of this essay was presented to the Law and Society Meetings, Phoenix, May 1994; and another part at the Society for Phenomenology and the Human Sciences, Seattle, Fall 1994. I have benefited from commentators.

* University Research Professor, 1996; Faculty of Law, University of Windsor, Canada.

1 See, for example, the admittedly early writing on feminist legal theory in Ellen C. DuBois et al., "Feminist Discourse, Moral Values, and the Law - A Conversation", Buffalo Law Review 34 (1985), 11-87; Heather Ruth Wishik, "To Question Everything: The Inquiries of Feminiat Jurisprudence", Berkeley" Women's Law Journal 1 (1985), 64-77; Ann C. Seales, The Emergence of Feminist Jurisprudence: an Essay", Yale Law Journal 95 (1986), 1373-1408, at 1374-80, 1402-03.

Martha Minow has emphasised that this focus on the categorical underlies traditional feminist analyais of difference. See Minow, "The Supreme Court 1986 Term, Foreword: Justice Engendered”, Harvand Law Review 101 (1987), 7-95, at 35, 76.78. Male law is projected as a rational set of beliefs or forms in Janet Rifkin, "Toward a Theory of Law and Patriarchy", Harvard Women's Law Journal 3 (1980), 83-95. More, man's view of the world is reduced to man's mind. The role of language is absent in this strain of writing.

2 Margot Stubbs, "Feminism and Legal Positivism", Australian Journal of Legal 


\section{Law and Critique Vol.VII no.2 [1996]}

Alfred Schutz's degcription of face-to-face relationg, an early moment of Critical Legal Studies called for a legal phenomenology of "intersubjective zap" or "unalienated relatedness"." Peter Gabel claimed, in the (in)famous dialogue entitled "Roll Over Beethoven", for example," that the Critical Legal Studies project aimed "to realise the unalienated relatedness that is immanent within our alienated situation".5 Our alienated condition is infused with suffering. This belief that a democratic society should strive to reach the face-to-face relations of an unalienated social condition has characterised an important theme of Critical Legal Studies in the United States.

In contrast with the abstractions with which lawyers had traditionally worked, face-to-face social relations embody an "unalienated relatedness". $\theta$ Gabel characterised such relations as "authentic". ${ }^{\top}$ Gabel feared that even the notion of "intersubjective zap" itself might become a frozen form in the same manner that "[a]ll utopian descriptions can be taken over and falsiffed to legitimate oppression and flight and alienation. ${ }^{n \theta}$ The true/ real lay in unalienated relatedness. ${ }^{9}$ Representations of past experiences displaced "the immediacy of connection" in favour of roles which lawyers absorbed through professional law achools, ${ }^{10}$ Intersubjective zap "overcame" this representative knowledge, Gabel believed. With the aid of "phenomenological description," people could learn the capacity "to

Studies 3 (1986), 63.

3 See, for example, Peter Gabel, "The Phenomenology of Rights-Consciousness and the Pact of the Withdrawn Selves", Texa Law Review 62 (1984), 1569-99; "Reification in Legal Reasoning", Research in Law and Sociology 3 (1980), 2551; "Intention and Structure in Contractual Conditions: Outline of a Method for Critical Legal Theory", Minnesola Law Review 61 (1977), 601-43.

4 Duncan Kennedy and Peter Gabel, "Roll Over Beethoven", Stanford Law Revietw 34 (1986), 1-65.

5 Ibid., at 1. Both Gabel and Kennedy recognized that atructural reformulations, in conceptual categories and principles in legal consciousness, posed the obatacle to unalienated conditions.

6 Ibid, at 3 .

7 Ibid, at 30 .

8 Ibid., at 6.

9 Metaphysics offers "a false form of unity that is imaginary in nature", ibid., at 29. To possess a radical view of how the ruling class "controls the law" is not enough, according to Gabel. This still mises "the essential point - that law is just a form of consciousness, a "belief-cluster." Ibid., at 31.

10 Ibid., at 6. 
understand in words with each other, in other words, to theorise or imagine with each other the meaning of what it was that just happened."11 We could share expression "in knowledge of what we already intuitively comprehended". ${ }^{12}$

More recently, Patricia Williams like Gabel, has argued that one can interpret without doing all the categorising which lawyers routinely do. ${ }^{\text {13 }}$ In examining equality cases, she described how the U.S. Supreme Court employs "interpretative artifice alone" and "rhetorical devices" to categorise "a backdrop of richly textured facts and proof on both local and national acales." This act of categorising the social circumstances in this manner is a "lawyerly game of exclusion and omission." In her notes in her first case she urged the jury "to revolt against the tyranny of definition-machines", "to name what your senses well know," and to describe what the jury "perceives to be the limits of sausage-justice."14 Phantom words "label". The definition machine itself is a thing (her emphasis). Lawyers "devour" meanings just as the sausage machines devour everything which lawyers place into the machine. The devouring filters out differences and thereby "đefaces" or disembodies an experiencing subject. ${ }^{15}$ Juridical definitions "conceal from any conaideration legal or otherwise - a range of serious but 'extrinsic' harms felt by the decisionmakers ....". ${ }^{16}$ The categorisation of Beethoven as white-skinned, for example, redefined Western culture generally and German culture in particular. Such a categorisation posited a boundary - the boundary of a category. The boundary "fragments" and "dehumanizes" to the point of constituting violence. Indeed, the boundary marginalises to the point of demeaning, masking, nullifying, obliterating or, at best, penalising the human being who ends up being extrinsic to the boundary. In order to cross the boundaries which the phantom words delineate, we must learn

11 Ibid., at 8.

12 Gabel insists that we can describe "existential reality at the level of reflection". Ibid., at 10.

13 See esp. "The Obliging Shell: An Informal Essay on Formal Equal Opportunity", Michigan Law Review 87 (1991), 2128. Her essay is published in The Alchemy of Race and Rights (Cambridge, Mass: Harvard Univeraity Press, 1991), ch.6.

14 Williams, Alchemy, ibid., at 107-08.

15 Just as Fred and Stanford University in general subtly concealed humiliation, even torture, through their "word boxes". Alchemy, ibid., at 110-15.

16 Williams, The Obliging Shell, supra n.13, at 2135. 
to acquire multifarious perspectives which Williams describes as "the ambivalent, multivalent way of seeing."

In order to learn how a lawyer might be able to cross metaphysical boundaries or, indeed, whether one can even do so as a representer of the modern state, it is necessary to address the authoritative character of the juridical discourse in a modern state. Lawyers privilege configurations of signs which are considered authoritative. The preoccupation of lawyers with authority, I suggest, complicates the facility with which face-to-face social relations could possibly characterise a legal discourse. The quest for authority moves the lawyer to differentiate between the words of a judge, say, and those of a poet or novelist or, for that matter, of a law professor.

But what makes a statute or judicial decision authoritative? Lawyers understand authority in terms of an author or source or foundation. Authority has not always been so identified. The later Greeks identified authority with the personality of a leader. With the Roman state, though, authority took on an impersonal air. ${ }^{17}$ This trace of authority to some impersonal foundation raises at least two importent issues. First, why should a juridical official carry on such a search for an impersonal transcendent foundation? Why should a lawyer or judge find it necessary to justify a statute, regulation, precedent, doctrine, rule, principle or other standard in terms of its rational justification vis-a-vis some author who is believed to constitute the foundation of the state's lawa? Why should such a juridical official seek out the intent of such a founding author? Secondly, as a juridical official continues the quest for the authority, is the subject transformed into a juridical person? If 80 , how is the subject transformed? And how does the subjectivity of a juridical agent get implicated in the process of compliance? How are the context-specific meanings of the non-official assimilated into the search for authority? After all, the citizen in a so-called liberal democracy may have no claim to "know" the intent of the Founding Fathers of a state. Nor may the citizen "know" what texts vie for the privilege of even being considered in the trace for authority. Nor may the citizen "know" which conceptions are represented by the texta' sigas. Nor may the citizen "know" how to analyze the texts, to differentiate amongst their rules, and to enclose social circumstances which the texts represent. This second issue, of the

17 See generally Leonard ICrieger, "Authority" in Philip P. Weiner, Dictionery of the History of Ideas: Studies of Selected Pivotal Ideas (N.Y.: Charles Scribner's Sons, 1968, 1973), 1.141-62. 
"how" of transformation, is the subject of another manuscript. ${ }^{18}$ I shall focus upon the first issue in this essay.

\section{An Author}

Who is this author which legal discourse seems to associate with authoritative texts? Michel Foucault has impressed upon us that the notion of an author is itself particular to an episteme which constructs the "author" from its own discourse. ${ }^{\text {ls }}$ But how has legal discourse understood the term "author" in the context of the professional's search for the legal authority for particular interpretations of texts?

When one uses the word "author", one usually thinks of a novelist, essayist, playwright, poet or composer. Novelists write from historically contingent circumstances about historically or fictitiously contingent circumstances. They are "historical authors". Their words signify or represent what the author intended. The author is believed to create or originate an object. The author's text represents her/his object. The author's act of creation is before and external to the text. The author wills an object and represents that object in a text.

So too, one may consider the reader of a text an "author" if the reader creates or wills an object in the text. Absent such a creator, the reader passively and impartially applies the author's conceptions to particular given circumstances. In a sense, the reader reads a statutory provision or a precedent as if the author of the text, situated chronologically prior to the reader, gazes upon the reader from afar. Not infrequently, a judge reads a text as if the judge had no choice in interpreting the text in the manner that $s$ he does. S/he reads as if her/his interpretation applies the object which the author - $\mathrm{a}$ legislature or judge - intended and as if the author had been all-knowing. The judge, as reader, acts like a surrogate of the author. It is pivotal that, as a surrogate, the reader reads the author's text impartially and neutrally. The reader must situate her/himself from the external vantage point of the author. S/he may represent the will of the author in circumstances which the author may never have contemplated or expected. Yet, if the juridical official treata

18 See William E. Conklin, "The Transformation of Meaning in Modern Legal Discourse: the Canadian Internment Camps", International Journal for the Semiotics of Law LX (1996), forthcoming.

19 Michel Foucault, "What is an Author?", in Paul Rabinow, ed., The Foucault Reader (New York: Pantheon, 1884). 
the text as positing an object, the official is an agent who stands in for the author of the text. Accordingly, the reader must purge her/his interpretation of her/his own feelings. The author posits the object which the text represents. The knower presupposes that the text belongs to the author, not to the reader. This sense of an "author" as a creator of texts permeates the early moments of legal positivism. Thomas Hobbes even called the parties to the social contract "authors". Once the authors agreed to the terms of the contract, "actors" in civil society enforced the authorg' intent. The foremost agent of the authors' intent Hobbes describes is "the Representer", "that great immortal god", more frequently known as the Leviathan or state. The authors granted authority to the actors to act on their behalf. And the actors apply the terms of the social contract in the spirit of the authorg' intent.

Jeremy Bentham took up the notion of the author and attributed the Legislature with the ultimate authorship of all posited laws. In his later works, he associated "the Peoplen with such ultimate authorship. One might even draw the notion of an author from Ronald Dworkin's claim that a hermeneutics underlies the judicial construction of a coherent single political theory which arguably emanates from the vague figure of an ultimate author. Dworkin's archetypical judges even possess mythological names. It is not a coincidence that Dworkin has judges appealing to the interpretive acts of these mythological judges in order to ensure the authoritativeness of an interpretation. One right answer dwells in the exercise.

If the notion of an author is familiar to the readera of early modern legal theorists or even of Dworkin, does such a notion figure in Hans Kelsen's Grundnorm which, after all, he describes as only an "act of thought"? And does the notion play a role in H.L.A. Hart's "unstated judicial practices", that anthropologically observable moment to which is attributed the foundation of the concept of law? It may be appropriate to describe such theorists as Hobbes and Rousseau as adopting the notion of the author as important to the foundation of civil laws. And it may be appropriate to describe Bentham and Austin as accepting en important role for the legislature as author. But Kelaen and Hart seem to depart from the sense of an author when they set the foundation of authority apart from authored texts. It is difficult to describe a concept or an empirically observable practice as gynonymous with an "author". 


\section{The Knower's Vision of the Invisible Author}

How, then, can one associate an "act of thought" or an "unspoken judicial practice" with the creative act of an author? Both Kelsen and Hart assert that authors posit objects through writing. What is very important in this context is that Kelsen and Hart differentiate an authored text from an unauthored or conventional practice. A judge may identify with a convention over a long period of time. Of course, conventions are often described as posited since they are imposed through human action. But a convention is also believed to be unwritten and, therefore, unauthored. One cannot identify the convention with an origin in a specific time and place. Nor can one associate it with one source or creator or willer. One does not know when the convention began. Indeed, one recognises a convention in writing after prior judges have accepted it, Hart points out. One just follows a convention. In contrast, one can never reach an immediacy with authored norms and rules.

If one believes that a rule is authored, the professional knower is drawn towards the given external object which a tert represents. The author's text refers to a distant object. A statute or regulation or reasons for a decision refer to objects; these objects are usually typifications or categories. So too, a judgement which summariges the evidence in a trial refers to the event which the evidence, in turn, is believed to represent. The ordinary legal text represents an object as a referent. Hart argues that primary rules refer to a rule of recognition as the source or ultimate criterion of validity of the rules. The object to which primary rules refer is external to the primary rules. In this case, according to Hart, the referent is an "unstated judicial practice" which secondary rules can only approximate. ${ }^{21}$ Even a rule of recognition is about a further object: namely, the "unstated judicial practices".23 Now, the foundation itself does not refer to some further object. If it did, the foundation would not be a foundation: it would not finalise, for there would still be some further object "out there" beyond the foundation. What had been taken as a foundation would be better described as an intermediate or second-order rule whose object judicial officials will. A founding criterion of validity must lack a further object as a referent. Fart acknowledges this important point. The "unspoken judicial practices" of Hart do not refer to

21 Ibid., at 107.

22 Ibid, at 94-96, 103. 
some further object. They are unspoken. One cannot trace them to one single authored text which could be said to represent an external object.

So too, Kelgen attributes a lack of a referent to the foundation of a legal system. Kelsen describes the Basic Norm as an act of thought which, in contrast with an act of will, lacks an object to be willed. An act of will is directed towards an object, Kelsen claims. But an act of thought lacks such an object. In a sense, Kelsen's "act of thought" is an "in itself". For both Hart and Kelsen, the foundation of all authored texts lacks a further object as referent. The foundation is, for Hart as for Kelsen, a pure, external "in itself".

Unable to know the object to which the foundation refers (because the foundation lacks auch a referent), the professional knowers of legal objects have a problem. For legal authority in a modern state, influenced by the juridical stoicism of the Romans, is associated with a foundation or ultimate source or arche point. But that source, to be a final foundation, must be object-less. Notwithstanding the inability of the expert knower to experience the lost moment of immediacy with the foundation of authoritative rules, the knower claims to know which authored rules are authoritative and which are not. And that claim goes to the knower's ability to represent the former, silent, unspoken, presupposed presence before historically contingent authors began to represent the moment through texts. Because the genre-like character of professional legal discourse holds out such a monopoly to such "knowledge", it is a quick, yet subtle, shift for the "knower" to consider the authored text to be binding upon her/himself and upon all other persons to whom the author intends the text to apply. Or so Kelsen, Fart and others assume. The necessity to find a finality to the seemingly interminable trace of historically authored texts necessitates a moment of presence which no juridical agent can admit to knowing. That moment is a moment of purity, untainted by the ad hoc, social contingencies of a historical author. But the lack of knowledge of such an originating moment drives the professional knowers on and on in their imperial quest to represent the social and the in itself alike. The professional knower in the modern legal genre is forever unhappy because $s$ he can never reach the originary foundation of a legal order. S/he can never do so because, if s/he did admit to doing 80 , her/his authored laws and her/his interpretation of such authored laws could no longer be considered finalised and, therefore, authoritative.

The best that a professional knower can do in the search to "know" the external, object-less foundation, is to picture or envision the foundation. 
The knower does so by representing the foundation. And this is the moment when the Roman notion of an "author" enters into Kelsen's and Hart's legal analysis. For the professional knower fills the vacuum, left by an absent, object-less foundation, by drawing a vague figure as the ultimate creator or originator of the absent foundation. A picture delineates boundaries. Boundaries include and exclude. The boundaries form a shape. The shape is vague and transparent until the knowera fill in the details of the picture. The texts which are believed to be authored - statutes, judgments and the like - paint a picture of a vague, shapeless, silent, radically ulterior other who stands beyond the texts as the first originator of a legal system. Professional knowers try to picture this radical other through their narratives and their doctrines and reasoning. Their representations give "body" to the formless and unrepresentable foundation. The "body", though, has no face behind which one might decipher a personality. The "body" is bodiless in that it does not possess a physiological or even an experiential character. The "body" of the absent foundation cannot be perceived; it floats through physical structures and through our networks of concepts. Judges recognise the contours of auch a bodiless body as they represent or, to use Hart's term, "approximate" the absent foundation through their signs. The more rigorously they analyse their picture of the vague foundation, the more it seems that they reach its identity. The effort of the professional knower is always a "second best", a picture of other pictures, a picture which represents a ghost-like auctor as the closest approximation of the foundation of authored laws.

Perhaps, one could best describe this ultimate represented auctor as a "ghost". ${ }^{2}$ We professional knowers try to map out the identity of what cannot be identified, an absent, founding, formless, signless Object. Of course, the body of the Object is not an organic or physiological body. Nor does it have experiences. One cannot picture the foundation with a particular dress or even with a face. The "body" of the absent Object is transparent in that it seems to converse through all physical and social impediments. Like a ghost the author who represents the originary moment of authority just seems to be ever present.

Why do I call this foundation of authority a ghost? A ghost lacks a body with flesh. A ghost does not posees property, the personal and real

23 Jacques Derrida, Specters of Marx: The Slate of the Debt, the Work of Mourning, \& the New International , trld. Peggy Kamuf with an introduction by Bernd Magnus \& Stephen Cullenberg (New York/London: Routledge, 1994). 


\section{Law and Critique Vol.VII no.2 [1996]}

property familiar to lawyers. ${ }^{24}$ More, a ghost lacks a phenomenal body, one that experiences. ${ }^{25}$ The emperor has no clothes. Yet, the ghost remains the body of someone. That someone is, Derrida points out in Specters of Marx, a someone other. The other at the end of the knower's vision of the absent foundation is ungraspable, irreducible and formless. ${ }^{26}$ Lawyers do not perceive this ghost 88 an other. Yet, such knowers treat their vision of the ultimate foundation of authority, this radical other to authored laws, as if the envisioned author gazes towards us from beyond any synchrony. As Jacques Derrida describea the gaze, "[a]nd even when it is there, that is, when it is there without being there, you feel the specter is looking, although through a helmet; it is watching, observing, staring at the spectators and the blind seers, but you do not see it seeing, it remains invulnerable beneath its visored armour." " Gazing at us from afar, we picture a creator who is believed to dress, to dissimulate and to protect juridical persons. As officers of the Court, we are guardians of the creator. Of course, legal positivism claims that the trace of our actions to the arche of authority is purified of morals and of history. Yet, the mysticism of religion creeps into our tracing project when we must respond to the issue, "what is it that lawyers trace in their quest for authority?" For we are left with an externally situated, ungraspable, bodiless spectre of a foundation which lacks a referent. Both Kelsen's "act of thought" (the Basic Norm) and Hart's "unspoken judicial practices" (the Foundation) haunt professional knowers as they trace the authority of a statute or a judicial decision through authored texts. The foundation of authority, even when the foundation is an a priori concept (Kelsen) or an anthropological practice (Hart), is an invisible Object which the knower can only envision as a ghost-like author.

We professional knowers are haunted by the spectre of a ghost as the founding author of legal language. More than just a apectre, we knowerg are haunted by the possibility that at some point in time and space, some Founding Fathers had actually experienced the foundation of authority as present. We act and interpret as if the ghost of such a presence gazes upon us from afar, as if the ghost directs us as to when we may detain another person, when we may execute her/him, when we may kill other men, women and children, and when we may do all these things, 80

24 lbid, at 41-22.

25 Ibid., at 131,

26 Ibid., at 7.

27 Ibid, at 100-01, 134. 
common during this century, authoritatively. Our genre, from the moment of the first day in a professional law school, induces us to believe that all acts and doctrines done in the name of the invisible Founder are real and practical. We feel constrained by its will. We reason as if the Founder allowed us no other choice in reaching a particular concluaion. Its gaze makes us see ourselves as passive representers and appliers of its will. Mindful of Canadian lawyers who, until recently, had escaped the influence of any realist tradition, ${ }^{28}$ the necessary belief in some ultimate Creator tempts the professional knower to believe that the knower does not even bring her/his own meaninge and experiences into picturing the foundation. Knowers cannot possibly have a dialogue with the spectre of the Author because the Author is not, and has not been, a living being who is capable of responding verbally or even in writing. We do respond to each other through our special language. We issue new configurations of signs in order to represent a more rigorous picture of the invisible auctor. The ghost, standing "out there" beyond this human world, just must be the final source for the authority of our acts. We must live our professional lives as if this mythical figure were an historical author at some moment in our constitutional history. The ghost-like figure is a myth in Barthes' sense of a myth being a second-level connotative meaning. $m$

And yet, as we interpret texts in its name, we analyse the objects which the texts represent. The more rigorous our analysis, the closer our voyage seems to take us to a full vision of the absent, silent foundation of legal authority. We knowers slowly and aubtly construct an identity for our image of the founder, thinking that the image is the true/real even though it is only a vigion. We envision the absent foundation in the image of a ghost who authors. We even give our image of the ghost a proper name with capital letters. We call it the Rule of Law, or Justice, or the Law, or the Original Intent, or Recht. Montesquieu best represented the spectre of the Ghost when he called it the "Spirit of the Laws". We professional knowers envision the ghost as we play through our semiotic

28 William E. Conklin, Images of a Constitution (Toronto: University of Toronto Press, 1989, 1994).

29 This is elaborated in Roland Barthes, "Myth Today", in Mythologies (London: Paladin, 1957), 109-59. Also see his "From Work to Text", in Josue U. Harari, Textual Strategies: Perspectives in Post-Sructuralist Criticism (Ithaca: Cornell University Press, 1979), 73-81; "Theory of the Text", in Rlobert Young, ed, Untying the Text: A Post-Structuralist Reader (Boston: Routledge, 1981), 31-47. 
configurations. We compete as to whose spectre of the ghost will dominate all others. We compete by privileging some configurations of signs over others. We write editorials and shout in demonstrations because claimants to other visions contravene the boundaries of our vision of the invisible Founder. We even go to war in defence of our image of the Ghost. Yet, precisely because we believe that we only objectively apply the will of an absent Object, our spectre of the Object resembles a Roman auctor.

The moment of creation of the external Object is not fixed in time and space. One cannot identify when it originated; nor whether it has died. Indeed, even after one picture of the ghost has replaced another through a revolution or a slow re-reading of the texts authored in its spirit, its representers may remain haunted by its spectre. Such happens during a civil war. We project a will into the Ghost. The Ghost does not create such a will for us to follow. Its will evolves as we make arguments or cite configurations of signs or make assumptions. As we continuously rediscover the will of the founding Author, we bring a rational unity to bear upon our own otherwise discontinuous fragments. We do so at the very moment that, in the name of the founding Author, we claim to represent an aggrieved.

\section{Surrogates of the Invisible Author}

Precisely because the presence of the invisible Author remains silent - it remains in a state of nature, a metaphyaics or a mythological world - surrogates lay claim to represent its presence through written instruments. The legislature, a precedent-setting court or a certified lawyer are believed to represent an "inside" knowledge of the invisible author's will at any contingent time and space. Such surrogates are believed to lie in a direct, if not close, connection with its will. The surrogates associate with each other, for example, in a profession which monopolizes knowledge of the spectre of the ghost. So too, one often hears judges and legal scholars giving little weight to the opinion of a political scientist or a criminologist or other "expert knower" because such claimants lie outside the lineage of authority directed towards the absent Object. They lack the authority of an "officer of the Court." As juridical officials proceed with their representation of the will of the invisible author, their opinions take on an air of certainty and clarity. Indeed, an experienced and "knowledgeable" lawyer may charge extraordinary fees 
becauge so many of her/his peers believe that g/he has reached close to the secret unknowable centre where the invisible author is situated alone. And the discourse of professional law teachera and scholars presupposes that their vision of the invisible author is clearer as they analyse authored texts in minute detail. Surrogates of the invisible author are also given proper names auch as the Kennedy Congress or the Burger Court. Sometimes, it seems that the surrogates are even referring to the ghost when they refer to "the intent of the Constitution", or "the letter and the spirit of the atatute" or "Justice dictates that ... ", or "the full weight of the Law ....". Again and again, jurisprudes and judges alike reconstruct the will of historical authors in the name of a far off entity named "the Law" or "the Administration of Justice".

This deference to some uncontrolling and uncontrollable ghost-like figure encourages the spectre of a rational, all-knowing, coherent and unifying fountain of justice. For there to be a unifying fount, there must be a single source behind any judge's or legislature's quest for authority. The trace of a juridical action to the statements of other surrogates, higher and higher on a hierarchic pyramid of authority-granting institutions, asaures any surrogate that her/his own statement is authorised. Legal discourge even hierarchises texts as if aome texts are closer to the will of the originating source than others. Texts are "grounded" as the trace proceeds. Texts become grounded without the ground ever connecting with the ghostly author of auctoritas.

Again, we professional knowers are haunted by the possibility that some final source founded our authority at some point in time. Wo are haunted by the loss of the immediacy which the Founding Fathers of our authoritative lineage once experienced. We gearch for their "original intent". We attribute the Founding Fathers of our Constitution with having had insight into the foundation, an insight which we contemporary guardians have not been granted. One reads from American Supreme Court decisions, for example, how judges are preoccupied with discovering the will of the Founding Fathers of the Constitution even though the Founding Fathers may never have addressed a particular issue. The spectre of an originating author enclothes the lawyer's own prejudice with authority. The trace of statutes and judicial decisions to such a spectre objectifies and formalises the historically contingent configurations of signs. The spectre of a ghostly author authorises the authored statutes and judicial decisions.

Yet, the professional knower - the lawyer, judge, legal scholar, law 


\section{Law and Crittque Vol.VII no.2 [1996]}

student - claims to possess inside knowledge about the intent of this ghost-like figure at the end of legal reasoning. The knower thereby crosses the line which had hitherto situated the ghost as separate from legal language. The knower guards the Castle of legal knowledge, just as Kafka narrates at the end of The Trial. The guardians of the Constitution look backwards as if the ghostly auctor had historically existed in point of time, as if its existence had been a contingent event. The auctor is the measure and evaluator of all juridical actions. We knowers write as if the ghost had lived before us in some almost forgotten moment of legal

discourse. Yet we write as if the ghost were just at the end of our gaze, in an objectless realm, in front of us today, immediately, staring at us, and bestowing guilt upon ua if we should act outside the boundaries of its will. We write as if the auctor may transform a being into a juridical peraon with rights and duties. Such a juridical person is believed to be equal "before" and "under" the auctor. We professional surrogates are terrified that beings live their lives without respect for the authority of their tracing project. Such a disrespect is contemptuous, seditious, treasonable, and deserving of violent constraint.

Legal discourse manifests the spectre of an invisible author in many ways besides the trace of justificatory reasons for action. In most common law jurisdictions, for example, the judge's particular views on politics, policy, morality and culture are considered outside the line of communication between judge and invisible author. The spectre of an invisible author is manifested in the construction of the curriculum for a professional law faculty. Studies of social justice, jurisprudence, semiotics, phenomenology, feminist legal atudies and all the many other diacourses which expose the violence and charade of searching for the ghostly vision of the invisible author are excluded or, at best, pushed to the side as a "perspective" or "policy" supplement to the "real" or "hard core" law courses. ${ }^{30}$ Surrogates for the invisible auctor hold auch discourses to be "impractical" or "unreal" or "critical rather than practical". Such supplementary issues are said to be left to politicians or academics whose utterances may carry little weight in the trace of authority. They concern the "wisdom", rather than the authority, of juridical action. Being outside the boundaries of an authoritative legal discourse, policy or moral issues lack the standing which the discourse attributes to statutes, regulations, precedents and, sometimes, highly

30 See generally William E. Conklin, Teaching Critically in the Modern Legal Genre", Canadian Journal of Law and Society B/2 (1993), 33-57. 
reified, encyclopaedic articles. That is, the "wisdom" and "morality" of any configurations of signs lack a possible nexus with the ghostly spectre of a unifying tranacendent author. Judge, lawyer, policeman, academic administrator and legal scholar: each excludes these iasues as extraneous to their trace of authority. The more socially bound to each other, the more natural does their claim to legal knowledge appear. The spectre of a ghost before (after) the foundation of authority constrains its representers.

Interestingly, precisely because the will of the founding author is unreachable from within historically contingent texts, expert knowers need to create an authoritatively protected profession which can protect and monopolise claims to know the identity of the ghost. This professionalisation of legal knowledge works to reinforce the external situs of the ghost-like auctor of authority. An expert professional clase may exclude other claimants to legal knowledge on the grounds that they are unqualified to speak on behalf of the ghost. In a sense, the intent of the founding Author is the self-identity of lawyers in a particular time and space. The members of the profession claim to "know" the inside intent with which legislatures and judges author their texts. Authoritative signs, in turn, privilege the monopoly position of the expert knowers to so represent the founding source of signs. Authority in the modern state thereby becomes self-perpetuating and self-binding. ${ }^{31}$ The certified representer of an aggrieved also speaks and acts as the surrogate for the founding Author of the atate's language.

So, the trace of precedents through chains of hierarchically situated precedents, the trace of regulations to statutes, quasi-constitutional and constitutional texts, the justifications of the rules and principles of other decisions in terms of higher-order reasons, the monopolization of the "how" and "what" of legal knowledge in a self-regulating profession: these factors work to manifest the spectre of an invisible author who founds the authority of a legal discourse. The architecture of their offices and the gestures of lawyers in the courtroom also manifeat the spectre of a founding auctor. The law office which a client enters for the first time, for

31 Stanley Fish, Doing What Comes Naturally (Durham \& London: Duke University Press, 1989). Renata Salecl, The Spoils of Freedom. Psychoanalysis and Feminism afer the Fall of Socialism (London \& New York: Routledge, 1994).

I examine the ramifications of Derrida's view of this self-referentiality in William E. Conklin, "The Trace of Legal Idealiam in Derrida's Grammatology", in Philosophy and Social Criticism 22/5 (1996), 17-42. 
example, usually possesses a cleanliness which one expecte of a pure source in contrast with the polluted, crowded stores and workplaces one usually visits in daily life. The furniture, the conspicuous carpeting, the etage of the law office in the office tower, the street address, and all the physical trappings which go with a professional law office or even a law faculty: these factors elevate the officers of the Court as if they represent some higher source then the rough and tumble of a mercantile economy.

As the judge enters the courtroom, the lawyers bow to her/his authority. The architecture of the courtroom elevates the judge above all other representers of the discourse. Eye-to-eye contact in the courtroom emanates from the highest surrogate to the lesser, and to the exclusion of all those whose languages lack a connection with the spectre of the invisible Author. The barrister's assistants take notes from the judge to the Court. The barristerg' and judge's black gowns elevate their reasons above their passions, their minds (as signified by the head) above their bodies. A wig cannot help but complete the symbolic disembodiment of the barrister as an official representation of the absent Object. Indeed, the colour black assimilates all competing colours at the same moment that it disfigures the juridical official as a living being.

The barrister's assistants write notes from the judge to the other surrogates. The heavy wooden panelling of courtrooms in many jurisdictions, the elevated bench for the judge, the lofty ceilings atretching to the heavens, and the disproportionately large lobbies of courthouses: even these architectural niceties reinforce the gaze of the absent auctor.

Let us look at the rhetoric between opposing lawyers. In order to express one's anger or objection to the conduct of another, the surrogate states, at most, "my client is concerned that ...". As the surrogates disagree amongst themselves, they preface their remarks with "with respect to my learned friend, my Lord". When the surrogates take issue with the judge, one hears "with respect, your Honour" or even with "with respect, your Worship". Of course, the surrogates do worship. They worahip a Source which, because if its inaccessibility within the historically contingent chains of signs, possesses a divine-like character. Both the factum and the eventual judgment summarise the case in an objective style. References to other signs from historical authors are frequently phrased in the passive tense: "it was held in such and such a case that ...". The evidence is reported as if the event occurred beyond the control of the lawyer: "it will be established that...". The lawyer's summary of the testimony of a witness is always represented in indirect 
speech: "witness X said that ...". Witnesses do not face each other in direct speech. The witness is physically situated above the others, alone, body hidden, separated from all other persons involved in the trial. The aggrieved and the defendant cannot respond to each other as the discourge unfolds in the courtroom. Nor may the aggrieved and defendant respond to the officers of the Court. Each is represented by an expert knower who writes, in turn, through magic terms which seem to automatically and inevitably signify or represent doctrines or statutory principles for the judge. Yes, each may be called as a witness. But each may only answer questions which are posed to her/him as a witness. The questions come from the surrogate of the Court. The surrogate chooses what inferences to make from each answer. The surrogate decides what the next question should be which $\mathrm{s} / \mathrm{he}$ believes follows from the prior answer. The questions are not final until the officer ends them. As a consequence, there is an absence of exchange in which each is a partner with the other. The plaintiff or defendant listens passively. S/he may agree or disagree. But, as Bakhtin describes monologues more generally, the addressee may not respond in the sense of drawing from the inter-textual space between lawyer and witness. Moreover, one frequently reade surrogates who disclaim any moral responsibility for their privileging of one configuration of signs over another. When the surrogate repeats the text of another gurrogate - a dictum in a judicial decision, the aection of a statute, a case name, a witness's statement, or a solicitor's pleadings, for example - s/he fuses such a text into a linear stream of consciousness which seems to emanate from beyond the surrogate. Even the " $I$ " of the lawyer/interpreter merges into the web of values, assumptions, styles and inages of the spectre of the Object. Configurations of aigns inter-weave into one coherent doctrine or narrative. The surrogate acts in the name of other surrogates who, in turn, define their roles in terms of their spectre of the absent Object. The life of the Law, it seerns, unfolds on its own. The possibility of a ghost which grounds all posited laws becomes the true/real.

Lawyers struggle with each other concerning "which representation best represents the ghostly spectre of the absent Foundation of legal authority?" Juridical officials trace their acts upwards through a hierarchy of "grounds" and backwards in linear time to the arche or foundation for which they may possess only an image, a vision, a spectro. The absence of the presupposed founding act ensures finality for the posited laws. Yet, its absence is and must remain a secret because to admit that the foundation of the autonomous legal order is a ghost-like 
figure would question the very authority of the posited laws themselves. The absence of the foundation ensures the autonomy of posited laws. Its absence ensures unity, rational coherence, harmony and a bourgeois peace amongst those citizens who also recognise the authoritativeness of the posited rules. Paradoxically, because surrogates themselves construct their vision of the Foundation, the grounding of posited laws is selfbinding and self-authorising. Once a judge's narrative is deprived of the possibility of a foundation, such a narrative returns to the genres of poetry, letters, and academic commentary. The narrative loses its power of enforcement. The narrative can no longer authoritatively constrain other juridical officials because the spectre of the invisible auctor has dissipated. The narrative becomes distant from the tracing project of the sausage machine. Deprived of a trace to the ghost-like auctor, the former surrogates must act as private citizens. Without author-ity, the former judge's categories can no longer authoritatively de-construct an embodied being into a reconstructed juridical person.

\section{The Tragedy}

Juridical officers speak, write, argue, gesture, and judge in an effort to situate an event in a linear trace of signs presupposed to emanate from an abaent object beyond them. In an effort to trace authority from one historically contingent author to another and, ultimately, to a presupposed moment of immediacy with the absent object which founds all authority, the professional knower begins legal analygis with the absent object rather than with the stories of suffering which an aggrieved may recount. For the trace of an official's judgment to some presupposed foundation of posited laws colours the judgment with impartiality, objectivity and a distance from the experiences of knower and aggrieved alike. In order for texts to carry the aura of posited laws, they must possess a finality. To be final, the text must be linked with a foundation which finalises the relation of one text with another. And that requires that the foundation be different from ordinarily posited texts. The foundation must be absent from the trace of aigns amongst texts. Ordinarily posited laws are authored whereas the final foundation of their authority carries an unauthored character about it. The foundation lacics a referent beyond it. The foundation has been described as pre-authored language and as an a priori thought. The founding object is forever inaccessible from within legal language. Itg inaccessibility renders the 
object invisible.

The inaccessibility of the final object drives professional knowers on to conquer all other discourses which might claim to envision the secret Object. In the quest to reach the absent foundation, the stories of the aggrieved are concealed. If justice dwells in the language of the aggrieved, the professional knower's trace of authority displaces the possibility of justice. ${ }^{92}$ The authositative language of the state addresses an absent object; it cannot address the particular other in the language of the other. As a consequence, the authoritative discourse is inevitably violent to an aggrieved. The face-to-face relations, which well-meaning legal scholars have aspired to recover for law, remain concealed within the trace of the authority of authored laws to some absent object.

This helps to explain why Patricia Williams, with whom I initiated this essay, compares legal language to a sausage-making machine. ${ }^{3 t}$ The juridical officials in the sausage machine re-present a diversity of experiences. Such experience, in the end product, become typified and uniform. They are signified through the lawyer's language which speaks in the name of an absent object. We lawyers re-circulate and repeat magic doctrines as if they are products to be consumed. Because our peers think like us, we take the typifications as constitutive of the whole of the true/real. We assume that some phantom auctor beyond the sausage machine has actually grounded the authority with which we act. That phantom auctor, we now realise, carries the transparent body of a ghost, perhaps a holy ghost.

The professional knowers are situated in a tragic paradox. Even when the historically contingent authors claim that universal human rights exist, at that very moment professional knowers search in vain for an absent Object which will authorise the claim. In the trace for authority, the search conceals the everyday languages of an aggrieved. The knower is left with a picture of a foundation whose absence must remain a secret. The closest which the knower can come to the foundation is to picture a founding author. Such a picture is of a ghost-like author who is believed to gaze from beyond the signs with which the representere are familiar.

32 As Derrida suggests in his reading of Benjanin's "Critique of Violence", legal discourae, however democratically enacted, is not and cannot be just. Jacqueg Derrida, "Force of Law: The 'Mystical" Foundation of Authority", trld. Mary Quaintance, Candozo Law Review 11 (1990), 919-1045.

33 Supra n.13, ch 6 . 
As a consequence, the authoritative discourse cannot face the aggrieved except to the extent that the discourse itself recognises and defines the other through its own familiar signs. The aggrieved being, whose pain may well have initiated a law case, becomes signified in an overriding search for authority. The aggrieved either becomes a juridical person or 8 /he is excluded as a non-person. In either case, s/he is de-faced and her/his body is of little worth except in economic terms. The signified representation of the aggrieved's experience becomes an event itself.

The face-to-face relations, which Critical and Feminist Legal Scholars have sometimes aspired to retrieve, remain deeply concealed inside the authoritative discourse of the modern state. The knower's search to envision a ghostly author of the absent foundation authorises the concealment. The professional knower can reach no closer than through a vision of a ghost. The inaccessibility of the voiceless and formless foundation takes on the character which Kant, in the Grounding of the Metaphysics of Morals and elsewhere, attributed to the divine. ${ }^{3 /}$ In his 1827 Lectures on the Philosophy of Religion, ${ }^{35}$ Hegel more pointedly associated such an external foundation with a particular sense of the divine: namely, Kant's. We modern knowers of the trace of authority are left with our own spectres of the foundation of authority. Bodiless. Faceless. Invisible. Spirit. Ghost.

The King is dead! God save the King!

34 Kant described the perfectly pure will as divine, "indeed holy" in Grounding for the Metaphysics of Morals, trli. James W. Ellington; (Indianapolis: Hackett Publ. Co., 1981).

35 The externality of the sublime is especially the subject of critique in Hegel Lectures on the Philosophy of Religion: The Lectures of 1827, ed. Peter C. Hodgaon (Berkeley/Los Angeles/London: Univeraity of California Press, 1988). 